\title{
Insider Interviews: Underground Music in the UK
} in the 2020s

$\mathrm{Vu}(e)$ s de l'intérieur : entretiens sur la musique underground au Royaume-Uni aujourd'hui

John Mullen, Stephen Gilbert and Jack Simpson

\section{OpenEdition}

Journals

Electronic version

URL: https://journals.openedition.org/rfcb/8400

DOI: $10.4000 / \mathrm{rfcb} .8400$

ISSN: 2429-4373

\section{Publisher}

CRECIB - Centre de recherche et d'études en civilisation britannique

\section{Electronic reference}

John Mullen, Stephen Gilbert and Jack Simpson, "Insider Interviews: Underground Music in the UK in the 2020s", Revue Française de Civilisation Britannique [Online], XXVI-3 | 2021, Online since 14 December 2021, connection on 04 January 2022. URL: http://journals.openedition.org/rfcb/8400 ; DOI: https:// doi.org/10.4000/rfcb.8400

This text was automatically generated on 4 January 2022.

\section{c) (1)}

Revue française de civilisation britannique est mis à disposition selon les termes de la licence Creative Commons Attribution - Pas d'Utilisation Commerciale - Pas de Modification 4.0 International. 


\title{
Insider Interviews: Underground Music in the UK in the 2020s
}

\author{
$\mathrm{Vu}(e)$ s de l'intérieur : entretiens sur la musique underground au Royaume-Uni \\ aujourd'hui
}

John Mullen, Stephen Gilbert and Jack Simpson

\begin{abstract}
We did not want to miss out on a view of underground music which does not come from Popular Music Studies in universities, but from practitioners and aficionados on the ground. We were able to interview two people from the North of England: Stephen Gilbert, a tremendously enthusiastic follower of new popular music, who lives in Blackpool, and Jack Simpson, a professional who encourages the production of avantgarde popular music in Leeds.
\end{abstract}

\section{Interview with Stephen Gilbert}

\section{JM: WHAT IS YOUR JOB AND HOW LONG HAVE YOU BEEN DOING IT?}

SG: I work at HMV, the last of the big highstreet entertainment chains in the UK and I've been there for fourteen years now. I started off in the DVD department but I always had more passion for music and working there has definitely helped keep my love for new music going.

JM: HOW MANY NEW BRITISH ARTISTS AND GROUPS WOULD YOU SAY YOU CAME ACROSS IN AN AVERAgE YEAR?

SG: Because I've made it my personal mission to listen to as much new music as I can I tend to listen to ten or more new releases each week. A lot of these end up being bands I've already heard and I try to listen to artists from all over, but I'd say there's normally at least two or three new British artists each week leading to between 120 and 180 new ones a year on a fairly average run. There's probably more than that if I count just the odd singles I hear throughout the year, but I tend to only count them if I've listened to a whole album by them. 


\section{JM: IS THE WORD “MAINSTREAM" MUCH USED IN YOUR JOB AND MILIEU TO REFER TO SOME UK POPULAR MUSIC TODAY?}

SG: The word mainstream definitely still gets kicked about a lot for music these days. Because I work at a big chain store there is plenty of what we sell that most people would consider mainstream and there is definitely a subset of music fans that would consider anything that makes it into a highstreet chain to be mainstream regardless of its popularity.

\section{JM: WHAT WOULD YOU SAY ARE THE MAIN CRITERIA THAT MAKES SOMETHINg PROBABLY "MAINSTREAM"?}

SG: It is certainly a harder thing to quantify these days, I think Chart success is still a big factor and any artist or group that can sell out decent sized venues is a good starting indicator. Anyone who has more than 500,000 monthly listens on Spotify or other big streaming services would definitely count towards it too. I suppose the final thing that singles you out instantly is if you have a song on a NOW compilation.

\section{JM: COULd YOU gIVE ME A FEW EXAMPLES OF UK POPULAR MUSIC WHICH YOU MIgHT CATEgORIZE AS MAINSTREAM?}

SG: At the moment we have a lot of big pop artists like Dua Lipa, Lewis Capaldi, Little Mix, Harry Styles, and Charli XCX. Then you have the increasing popularity of Grime and other forms of UK Hip Hop with acts like Stormzy, Skepta, Aitch, Slowthai, AJ Tracey, and Little Simz. Our other big export has always been "Indie" music and artists like IDLES are still making big waves but most of it still lies slightly under the surface of the mainstream.

\section{JM: IS THE WORD “UNDERgROUND” MUCH USED IN YOUR JOB AND MILIEU TO REFER TO SOME UK POPULAR MUSIC TODAY?}

SG: Underground is a word that I still hear thrown around, but it's one of those things that everybody has a different idea as to what really counts. I'd argue that bands that don't get regular plays on radio or get frequently covered by online music pages fall within it, but others would suggest that as soon as you have a record label then you can't be counted as underground any more. I think it is still a very important idea for music fans though because everybody loves the idea of finding something early on or knowing about things that other people haven't discovered yet. It also tends to indicate that something is going to be different to the stuff you're hearing on a day to day basis and I think there is always a little rush to finding something that is bizarre and "Outsider". There are always people who feel the need to gatekeep and will do anything within their power to say that what THEY like is truly underground and what YOU like is mainstream but more often than not their definitions are very inconsistent

\section{JM: WHAT WOULD YOU SAY ARE THE MAIN CRITERIA (MODES OF DISTRIBUTION, AESTHETIC OR SOCIAL VALUE ETC.) THAT MAKES SOMETHINg PROBABLY “UNDERgROUND"?}

SG: I think for something to really fit the bill it has to be something that has a fan base but hasn't broken into the popular consciousness yet. Although there are plenty of people releasing things on Soundcloud and Bandcamp, or doing gigs in tiny venues I don't think that automatically makes you underground. There has to be at least a small following. The content of the music also plays a big part in it, anti-authority and overtly political music often ends up in the underground and it is more likely to have an experimental bent to it. 


\section{JM: COULD YOU gIVE ME A FEW EXAMPLES OF UK POPULAR MUSIC WHICH YOU MIgHT CATEgORIZE AS UNDERgROUND?}

SG: There's still plenty of underground releases from the UK at the moment but there's a few things that stand out to me. There is a massive Post Punk revival going on at the moment that has mainstream success in artists like IDLES but contains lots of smaller artists like Shame, Sports Team, HMLTD, Sleaford Mods, Black Midi, and Black Country New Road. We are currently also seeing a massive influx of British Jazz like The Comet Is Coming, Moses Boyd, Sons Of Kemet, GoGo Penguin, and Jazz Punk act Melt Yourself Down. Mainstream artists like Dua Lipa and Jessie Ware have been riding a wave of disco revival that bands like Sink Ya Teeth and International Teachers of Pop have been working on for the last few years. There's plenty of artists and groups who are releasing albums that are regularly making it onto best of the year lists, even if they aren't making the same amount of money and there's plenty of other artists like Nadine Shah, Kelly Lee Owens, and Kate Tempest who are making great music that is just slightly outside of the mainstream.

\section{JM: DO YOU THINK THESE TERMS ARE MORE USED TO SPEAK OF THE POPULAR MUSIC OF THE PAST, BEFORE THE DOMINATION OF THE INTERNET?}

SG: With how complicated the application of the term has become I'd say it's definitely easier to attribute it to artists of the past, but honestly I believe that the underground scene is as strong if not stronger because of how easy it is to find new music now. Although we don't have as many fanzines as in the old days, the internet allows for fans of even the nichest of bands to come together and helps them to find even more. The days of passing around mix tapes is behind us, but now you can make hours of playlists on streaming sites to share with your fellow fans. To some people the word underground will conjure up acts like Carter USM or Ned's Atomic Dustbin, but it is still a scene that is alive and well just not necessarily referred to as underground by the people who are listening to it.

\section{Interview with Jack Simpson}

\section{JM : WHAT IS YOUR JOB IN CONNECTION WITH CULTURAL PRODUCTION TODAY AND HOW LONg HAVE YOU BEEN DOINg IT?}

JS : I do various things in culture. I own and run two venues, one of which has a recording studio \& rehearsal rooms (primarily for music). The other is more a cafe / bar / social space. Alongside this I help project manage an array of things, a record label, some other people's creative projects, the Leeds Lit Fest, a Spoken word record label...

\section{JM : IN THE FIELD OF MUSIC, HOW MANY NEW BRITISH ARTISTS AND GROUPS WOULD YOU SAY YOU CAME ACROSS IN AN AVERAgE YEAR?}

JS : Oh, hundreds.

JM : IS THE WORD “MAINSTREAM" MUCH USED IN YOUR JOB AND MILIEU TO REFER TO SOME UK POPULAR MUSIC TODAY?

JS : Sure. 
JM : WHAT WOULD YOU SAY ARE THE MAIN CRITERIA THAT MAKES SOMETHINg PROBABLY "MAINSTREAM"?

JS : I think the main thing would be a lack of friction between the article in question, or the people behind it, and their attitudes to day to day norms. Which we might unsubtly refer to as those norms relating to the commodification of all.

\section{JM : COULd YOU give ME A FEW EXAMPLes OF UK POPULAR MUSIC WHICH YOU MIght CATEgORIZE AS MAINSTREAM?}

JS : I'd struggle to suggest right now; music that's not mainstream, in some sense. That might be easier.

JM : IS THE WORD “UNDERgROUND” MUCH USED IN YOUR JOB AND MILIEU TO REFER TO SOME UK POPULAR MUSIC TODAY?

JS : Not so much, a little. Where it is, it feels hard to really see anything particularly not mainstream about it, in most cases. IE, its use seems an attempt to point to a division, a space, that once was, but is mostly, no more.

JM : WHAT WOULD YOU SAY ARE THE MAIN CRITERIA (MODES OF DISTRIBUTION, AESTHETIC OR SOCIAL VALUE ETC.) THAT MAKES SOMETHINg PROBABLY “UNDERgROUND"?

JS : I don't really think there is a great space for this right now. There is more... Mainstream, and that which has failed to become mainstream. There is difficulty in surviving outside of the mainstream right now. TINA is prevailing perhaps.

JM : COULd YOU giVe ME A FEW EXAMPLES OF UK POPULAR MUSiC WHICH YOU MIght CATEgORIZE AS UNDERgROUND?

JS : There are elements of things like mumble, trap, there's maybe some jazz, but I don't think the mainstream - underground distinction holds like it once did.

JM : DO YOU THINK THESE TERMS ARE MORE USED TO SPEAK OF THE POPULAR MUSIC OF THE PAST, BEFORE THE DOMINATION OF THE INTERNET? IF SO, WHY DO YOU THINK THIS IS?

JS : I think from the 90s, our political landscape shifted and that blurred the lines for much culture. A third way descended on much space which sucked some centre left elements of society in with it. The internet is important, but it's only part of the story. The grander shift is the combination of technological development, with, and mobilised by, an ideological shift. 